\title{
JUURNAL.RU
}

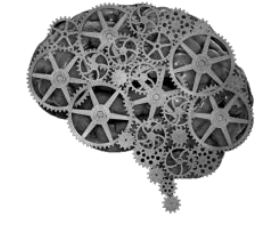

COMPANY GROUP "INTELLEKT"

\author{
Пьянкова Л.А., Рундау Т.А. \\ Сибирский государственный индустриальный университет \\ Новокузнецк, Россия
}

doi: 10.18411/lj2016-3-73

\section{Семья, родительство и детство как явления современной жизни}

Анализ теоретических исследований по проблеме культуры брачносемейных отношений, различных контекстов феномена родительства позволяет утверждать, что семейные проблемы универсальны. Именно семья и схожесть процессов происходящих в ней у людей разных национальностей и вероисповеданий, делает всех нас людьми одной эпохи, землянами, гражданами государств, представителями цивилизаций и выдвигает одни и те же проблемы. Никогда еще нравственные устои семьи и детско-родительские взаимоотношения не подвергались такому испытанию во всем мире, как сейчас, и никогда, пожалуй, мир не нуждался во всеобщем осмыслении таких понятий как единство, гуманизм, честность, открытость, порядочность, которые во всей совокупности прочих показателей не только ускоряют общественный прогресс, но и выступают сдерживающим фактором для человека [1].

На протяжении истории взаимоотношения родителей и претерпевали трансформации, что нашло отражение в таких стилях взаимоотношений к детям, как:

- инфантицидный - детоубийство, насилие (с древности и до IV в. н.э.);

- бросающий - ребенка отдают кормилице, в чужую семью, в монастырь и пр. (IV - XVII вв.).

- амбивалентный - дети не считаются полноправными членами семьи, им отказывают в самостоятельности, индивидуальности, «лепят» по 
«образу и подобию», в случае сопротивления жестоко наказывают (XIV - XVII вв.);

- навязчивый - ребенок становится ближе родителям, его поведение строго регламентируется, внутренний мир контролируется (XVIII в.);

- социализирующий - усилия родителей направлены на подготовку детей к самостоятельной жизни, формирование характера; ребенок для них объект воспитания и обучения (XIX - начало XX в.);

- помогающий - родители стремятся обеспечить индивидуальное развитие ребенка с учетом его склонностей и способностей, наладить эмоциональный контакт (середина XX в. - настоящее время) [2].

Выступая связующим звеном между обществом и личностью, фоном, на котором происходят переплетения внешних условий и внутренних побуждений людей, объективных и субъективных воздействий разнообразных факторов, семья в России на современном этапе демонстрирует следующие основные тенденции воспитания детей:

- наличие нетипичных проблем, решение которых не может опираться на опыт предшествующих поколений в виде подходов и механизмов;

- отсутствие единой системы ценностей как основы воспитания в условиях трансформации внутрисемейных и общественных отношений: алкоголизации родителей, фактически приводящей к девиантному отцовству и материнству, росте неполных семей, в которых дети воспитываются одним родителем; уменьшении ценности брака, семьи и особенно детей по сравнению с ценностями материального благополучия и достатка; непонимании некоторой частью молодежи проблем и трудностей семейной жизни, взаимных прав и обязанностей в семье; росте количества семей с единственным ребенком, что не обеспечивает даже простого воспроизводства населения; увеличении числа разведенных мужчин и женщин, которые затем не могут или не хотят повторно вступать в брак; значительном росте разводов по этико-психологическим 
мотивам и причинам сексуальной несовместимости супругов, а, следовательно, неудовлетворенности интимной стороной супружеской жизни;

- тенденции к свободному воспитанию, позволяющему ребенку делать все, что он захочет по принципу «никакого насилия», нередко такие явления проистекают из неполной структуры семьи, когда ребенка воспитывает только мать, либо эти функции выполняет бабушка при живых родителях, рассогласования между претензиями и возможностями родителей, безответственным отношением отца («невидимого дисциплинатора») к своим обязанностям, что фактически можно расценивать как устраненность мужчины от воспитания детей;

- наличие серьезных соперников у родителей в виде компьютера, телефона, телевизора и т.д., которые отодвигают на периферию непосредственное, «живое» детско-родительское общение и его возможности для воспитания ребенка;

- тяготение значительной части родителей к воспитанию ребенка по принципу кумира семьи;

- появление большого количества сверходаренных детей и т.д.

- Что касается Запада, то для большинства стран характерно следующее:

- широкая пропаганда толерантности, подчас противоречащая христианским ценностям, на основе которых веками строилась культура Европы, предлагающая воспитывать у ребенка терпимое отношение к любым проявлениям личности, включая то, что еще совсем недавно считалось извращением или заболеванием, например, гомосексуализму;

- наличие ювенальной юстиции ставит западных родителей в условия жесткого выбора между тем, как они считают нужным воспитывать детей, и тем, как видит процесс воспитания общество;

- вызовы нового времени - в ряде стран (например, в Голландии) принимаются законы, позволяющие ребенку менять пол по своему 
желанию, не достигнув совершеннолетия; также недавно был принят закон, позволяющий применять эвтаназию к детям по их желанию и т.д. [3;4].

Общеевропейской тенденцией является снижение уровня рождаемости, увеличение возраста женщин, впервые становящихся матерями, увеличение количества рождений у мигрантов и т.д.

Хотя снижение рождаемости - тревожная тенденция и для нашей страны, тем не менее, причины, по которым люди не спешат обзаводиться детьми, либо рожать второго и последующих детей, носят, в большей степени, экономический характер, хотя существуют и другие: общая семейная неудовлетворенность, сопровождаемая состояниями монотонности, скуки, бесцветности жизни, когда мучают воспоминания о «прелестях» добрачной жизни, кризисы возрастного развития, чрезмерное планирование дел, не оставляющее времени, места и желания иметь детей, существующие в обществе социальные законы деторождения, повторные браки, овдовение и др. Перечисленные причины можно отнести к группе психологических, нравственных, которые связаны с духовно-нравственным состоянием общества в целом. Можно предполагать, что улучшение экономических условий в стране положительно повлияет на демографическое поведение населения и в какой-то мере приведет к нравственному оздоровлению общества на фоне удовлетворения витальных потребностей конкретного индивида. Меры демографической политики, принятые Правительством РФ в 2007 г. принесли свои плоды - уже в 2009 «русский крест» начал расходиться, т.е. рождаемость начала превышать смертность, правда, всего на доли процента, но и это было позитивной тенденцией.

Тем не менее, как следует из доклада вице-премьера правительства РФ О. Голодец на Координационном совете при президенте РФ по реализации национальной стратегии действий в интересах детей на 2012-2017 годы рождаемость в России не достигает уровня, необходимого для простого 
воспроизводства населения [5]. На сегодняшний день коэффициент рождаемости в России достиг 1,75 ребенка на женщину в фертильном возрасте. В 2014 году в РФ родилось на 37 тыс. детей больше, чем в 2013 году и составило 1,947млн. детей. Это самый высокий результат после 1990 года [5]. По данным данные Росстата, в 2015 году в РФ заметно снизились показатели рождаемости.

За первые пять месяцев 2015 года россиянки родили на 16,7 тысячи детей меньше, чем за тот же период 2014 года. Причем снижение рождаемости было зафиксировано в 66 из 85 регионов страны. Согласно статистическим данным, это первое подобное проседание рождаемости с 2000 года. В течение 15 последних лет прирост населения в РФ постепенно поднимался. Особенно это было заметно в сравнении с 1990-ми годами, когда рождаемость падала. По мнению экспертов, падение рождаемости связано с тем, что в репродуктивный возраст вступило поколение россиян, родившихся в 1990-е. Дело в том, что это поколение довольно малочисленно. Кроме того, специалисты в области экономики, демографии не исключают и влияние экономического кризиса, начавшегося в России в прошлом году. Так, по данным Росстата, начала падать рождаемость, тогда как для простого воспроизводства населения без прироста численности необходим суммарный коэффициент рождаемости 2,11 - 2,15 [6]. Согласно прогнозу в обнародованном в начале октября 2009 года докладе «Программы развития ООН», Россия потеряет к 2025 году 11 миллионов человек населения. Страна вступила в период массового преобладания малодетной семьи. Всё больше семей ориентируются на одного ребенка с откладыванием его рождения. Постоянно растет доля детей, родившихся вне зарегистрированного брака. Эти тенденции также подтверждают данные социологического опроса ВЦИОМ, проведенного в 2008 году. Их данные свидетельствуют о том, что почти две трети россиян (60\%) не имеют детей и не планируют обзаводиться ими. Всего 5\% опрошенных россиян собираются завести детей в ближайшие год-два. Каждый третий (34\%) является родителем, $22 \%$ имеют одного несовершеннолетнего ребенка, $10 \%$ - двоих детей, $2 \%$ - более 
двух детей. Россия занимает в списке 40 промышленно развитых стран мира первое место по числу абортов на число родившихся (до 1995 г. - второе после Румынии) [7]. В последние годы наметилась тенденция к снижению числа абортов. Так, если в 1990 году в нашей стране было проведено 4,1 млн. абортов, то в 2000 - 2,1 млн., а в 2010 - 1,05 млн., в 2011 - 990 тыс., в 2012 - 940 тыс., в 2013 г. - 890 тыс. [8]. И это официальные цифры, реальная ситуация может быть совершенно другой, поскольку не учитывает количества подпольных абортов

Таким образом, кризисные явления в экономике, сфере нравственных отношений граждан проникают в семью, проявляясь в вопросах воспитания, отношении к детству как к периоду жизни и процессам социализации подрастающего поколения, а также тех явлениях, которые существуют в популяции детей: антигуманность, снижение этических, нравственных критериев, отказ от своих культурных корней. Так, среди школьников России распространены тревожность, пессимизм, неверие в светлые жизненные перспективы [9]. Эти тенденции характерны и для других стран. Во Франции, например, из 5 тыс. опрошенных подростков в 2008 г. каждый второй заявил о разочаровании в таких ценностях, как гуманизм и прогресс. Из опрошенных в 2012 г. 12 тыс. японских школьников 39\% увидели будущее в сером цвете, 15\% в черном. Среди детей и подростков усиливаются инфантильные тенденции: недостаточная самостоятельность, скудный опыт социальной жизни. К примеру, в Японии, как показали исследования 2005 г., 46\% школьников не встают по утрам самостоятельно, 56\% не убирают свою комнату, около $35 \%$ школьников никогда не готовили себе еду. Дети часто не умеют выполнять элементарного: затачивать карандаш перочинным ножом, не могут хорошо отжать мокрую тряпку и пр.

За последние 40 лет средний школьник значительно подрос. Так, более ранними становятся сроки полового созревания. Весьма заметна, например, физическая акселерация детей в Японии. Рост выпускника начальной школы с 
1950 по 2012 г. увеличился на 13,5 см, выпускника младшей средней школы - на 17,7 см, выпускника старшей средней школы - на 8,9 см. Соответственно средняя масса - на 9,5; 15; 9,8 кг. Аналогичные явления наблюдаются и в других странах мира.

В связи $\mathrm{c}$ физической акселерацией детей возникли серьезные педагогические проблемы. Как замечает японский исследователь С. Мураяма, поскольку у школьников взросление души не поспевает за физическим развитием тела, возникает разлад между переполняющей душу энергией и общепринятыми нормами поведения [10].

Нарастает опасность дегуманизации подрастающего поколения. Мир переживает вспышку наркомании, алкоголизма, проституции, преступности среди подростков. Многие школы захлестнула волна насилия. Эти тревожные явления - следствие роста нечувствительности многих подростков, что опустошает их внутренний, духовный мир. Жертвами издевательств обычно оказываются наиболее развитые дети, что отражает специфику детских отношений, в которых часто присутствует болезненно-нервозная реакция при контактах различающихся по уровню развития интеллекта подростков.

Проведенный теоретико-практический анализ проблемы семьи, детей и детства дает основания считать о нарастающей опасности деформации семейных устоев, наследования культурно-исторического семейного опыта. В эпоху цивилизационного слома, когда произошел реальный переход человечества в исторически новое состояние, приведший к переоценке ценностей, снятию разного рода барьеров, которые, между тем обладали и сдерживающим фактором в принятии решений для многих людей, общество, его социальные институты и отдельные индивидуумы оказались в новых обстоятельствах [9]. И это требует консолидированных усилий образовательных, государственных, социальных учреждений, ученых, педагогов, врачей, психологов, нацеленных на сохранение семьи как социального института, транслирующего приоритетные ценности осознанного, 
ответственного родительства, детности и детства, выступающих одновременно и ресурсами общества, несущего не только воспитательный, социальноэкономический, но и культурный потенциал для его развития в новых непростых условиях.

\section{Литература:}

1. Пьянкова Л.А. Материнство как феномен развития общества и личности : моногр. / Л.А. Пьянкова. - Новокузнецк : Изд-во КузГТУ, 2014. - 89 с.

2. Психология семейных отношений с основами семейного консультирования ред. Е.Г. Силяева М.: Издательский центр «Академия», 2002. - C.3.

3. Алексеева Э. Р. Анализ семейных форм социального родительства в современной России / Э. Р. Алексеева // Вестник Башкирского университета. Сер. «Философия. Политология. Социология. Культурология». - 2008.- Т. 13. — № 3.- С. 644-646.

4. Богачёва Н.В. Родительство как фактор устойчивости семьи в современном российском обществе : дисс. ... канд. соц. наук : 22.00 .04 / Богачева Н. В. - Казань, 2005. - 245 с.

5. Голодец: коэффициент рождаемости в РФ, запланированный на 2018 г., уже достигнут / ТАСС Информационное агенство [Электронный ресурс] URL: http://tass.ru/obschestvo/1994565. - Загл. с экрана.

6. По данным Росстата, в России начала падать рождаемость 03:35, 30 июль 2015 [Электронный pecypc] - URL: http://www.uznayvse.ru/vrossii/74844.html.- Загл. с экрана.

7. Федосеев А.Н. Уничтожение морали и нравственности в России [Электронный pecypc] - URL: http:/rysrhipelag.ucoz.ru/publ/a_n_fedoseev_unichtozhenie_morali_i_nravstven nosti_v_rossii/38-1-0-4206. - Загл. с экрана. 
8. Аборты в России: как расстаться с позорным лидерством? / Алексей УЛЬЯНОВ [Электронный ресурс] - URL: https://www.miloserdie.ru/article/aborty-v-rossii-kak-rasstatsya-s-pozornymliderstvom/. - Загл. с экрана.

9. Фельдштейн Д.И. Современное Детство: проблемы и пути их решения // Вестник практической психологии образования. 2009. № 2. С. 28-32.

10. Воспитание в России и за рубежом. Автор/создатель: Джуринский А.Н. [Электронный ресурс] - URL: http://window.edu.ru/catalog/pdf2txt/091/28091/11313?p_page=2. - Загл. с экрана. 